Vesicoureteric reflux occurred in eight infants with bacteriuria. This was regarded as being slight in two instances and moderate in six. There seemed to be no relation between the presence of vesicoureteric reflux, raised blood urea levels, proteinuria, and symptomatic infection. All cases of moderate vesicoureteric reflux were associated with asymptomatic bacteriuria in the neonatal period. Three to four weeks were allowed to elapse after the episode of bacteriuria before the radiological studies were performed.

The screening of 1,460 consecutive infants for bacteriuria did not reveal any examples of obstructive uropathy on further investigation. Moreover, while vesicoureteric reflux was often found, it was not of the gross variety (see Table III). Recently, it has been shown that probably only this gross variety of vesicoureteric reflux is associated with progressive renal damage in a high proportion of cases (Rolleston et al., 1970).

I would like to thank the following: the Royal Australasian College of Physicians and Glaxo Laboratories (England) for financial support; Sisters J. Worrall, L. Bugden, and G. Dann for technical help; and Dr. F. T. Shannon for advice and encouragement.

\section{References}

Abbott, G. D. (1970). British Medical fournal, 1, 207. Abbott, G. D., and Shannon, F. T. (1970). Clinical Pediatrics, 9, 277. Bailey, R. R. (1970). New Zealand Medical fournal, 71, 216.

Bernstein, J., and Brown, A. K. (1962). Pediatrics, 29, 873.

Cowan, S. T., and Steel, K. J. (1965). Manual for the Identification of Medical Bacteria. London, Cambridge University Press.

Cruickshank, G., and Edmond, E. (1967). British Medical Fournal, 4, 705.

Hamilton, J. R., and Sass Kortsak, A. (1963). Journal of Pediatrics, 63, 121. Littlewood, J. M., Kite, P., and Kite, B. (1969). Archives of Disease in Childhood, 44,617.

Mabeck, C. E. (1969). Lancet, 2, 1150.

Mackie, T. J., and McCartney, J. E. (1960). Handbook of Bacteriology, ed. R. Cruickshank, 10th edn., p. 303. Edinburgh, Livingston.

O'Brien, N. G., Carroll, R., Donovan, D. E., and Dundon, S. P. (1968). Fournal of the Irish Medical Association, 61, 267.

O'Doherty, N. J. (1968). In Urinary Tract Infection: Proceedings of the First National Symposium, ed. F. O'Grady and W. Brumfitt. London, Oxford University Press.

Rolleston, G. L., Shannon, F. T., and Utley, W. L. F. (1970). British Medical Fournal, 1,460 .

Shackman, R., and Messent, D. (1954). British Medical fournal, 2, 1009.

\title{
Immunoglobulin Levels in Newborn Infants with Hepatosplenomegaly
}

\author{
K. L. TAN, Y. C. CHAN
}

British Medical fournal. 1972, 1, 269-270

\section{Summary}

Serum IgM and IgA levels were measured in 97 newborn infants with and 141 without hepatosplenomegaly. All were considered normal at birth and had no apparent disease on clinical examination. Thirty per cent. of the infants with hepatosplenomegaly were found to have IgM levels of $20 \mathrm{mg}$ / $100 \mathrm{ml}$ or greater, a level established as abnormal when compared with the control group. The number of infants with raised IgM level and the geometric mean level were significantly different $(P<0.001)$ from those in the control group. No difference, however, was found in serum IgA levels between the two groups of infants. The results suggest that intrauterine infections may sometimes be the cause of hepatosplenomegaly in newborn infants without apparent disease.

\section{Introduction}

The liver is palpable in almost all, and the spleen in some, normal newborn infants (McNicholl, 1957; Nelson, 1969). In some infants the liver is enlarged beyond normal limits and the spleen is obviously palpable. Except for the hepatosplenomegaly these infants show no other abnormalities and were considered to be normal at birth.

Hepatosplenomegaly in the normal newborn infant probably has a varied aetiology, including infection in utero. It is a common, and may be the only, clinical manifestation in intrauterine infections (Stern and Tucker, 1965; Overall and Glasgow, 1970). Intrauterine infections have been shown to be associated with raised IgM levels in infants, and the quantitation of this immuno-

Faculty of Medicine, University of Singapore, Singapore 3

K. L. TAN, M.R.C.P.ED., D.C.H., Senior Lecturer, Department of Paediatrics Y. C. CHAN, B.SC., PH.D., Senior Lecturer, Department of Bacteriology globulin in cord sera has been shown to be a useful screening test for detecting mild or "silent" infections (Alford, 1971). This communication describes the results of immunoglobulin determinations in a group of newborn infants with hepatosplenomegaly and shows that this abnormality at birth, in some infants at least, may be associated with a clinically inapparent intrauterine infection.

\section{Patients and Methods}

Ninety-seven newborn infants delivered in the Kandang Kerbau Hospital in Singapore between December 1968 and March 1970 were studied. These infants were considered to be normal at birth except that they presented with an enlarged liver ( $\geqslant 3 \mathrm{~cm}$ below the right costal margin) and spleen $(\geqslant 1 \mathrm{~cm})$. They included both sexes in the three major ethnic groups (Chinese, Indian, and Malay) and their ages ranged from 6 hours to 3 days. One hundred and forty-one normal newborn infants who had no hepatosplenomegaly were also studied. These control infants were delivered in the same hospital from February to July 1970 and they were matched for ethnic group, sex, and age.

A complete blood count was made and radiological examination of the long bones was carried out on the infants with hepatosplenomegaly. Umbilical cord blood or blood obtained by venepuncture within three days after birth was examined for immunoglobulins IgM and IgA by a modification of Mancini's single radial immunodiffusion (Mancini et al., 1965). Standard human serum and specific antisera were supplied by Hoechst Pharmaceuticals Ltd. The details of the method will be published elsewhere. The coefficients of variation for the standard serum determined from 40 estimations over a nine-month period were $6.3 \%$ for IgM and $6.2 \%$ for IgA. In this study cord sera in which IgA levels were higher than IgM levels were thought to be contaminated with maternal blood due to placental leak and were excluded from analyses. Immunoglobulin concentrations were converted to logarithms for statistical analyses. 


\section{Results}

The IgM concentrations in cord sera and sera obtained within the first six days of life in the control group of infants are presented in Table I. There was no significant increase in the geometric mean IgM level in sera taken within the first three days of life. The IgM concentrations increased significantly from the fourth day onwards. In this study the sera of infants with hepatosplenomegaly collected within three days after birth were used for comparison with cord sera in the control group.

The geometric mean for IgM concentrations in the 141 control cord sera studied is given in Table II. Ninety-seven per cent.

TABLE I-IgM Concentrations ( $\mathrm{mg} / 100 \mathrm{ml}$ ) in Cord Sera and Sera Obtained Within the First 6 Days of Life in Control Infants

\begin{tabular}{|c|c|c|c|c|c|}
\hline \multicolumn{3}{|c|}{ Specimen } & \multirow{2}{*}{$\begin{array}{c}\text { No. Tested } \\
108 \\
16 \\
17 \\
20 \\
15 \\
12\end{array}$} & \multirow{2}{*}{$\begin{array}{c}\text { Geometric Mean } \\
9 \cdot 7 \\
9 \cdot 4 \\
9 \cdot 4 \\
11 \cdot 7 \\
14 \cdot 4 \\
17 \cdot 4\end{array}$} & \multirow{2}{*}{$\begin{array}{c}\text { 土2 Standard } \\
\text { Deviations } \\
5 \cdot 0-19 \cdot 0 \\
4 \cdot 6-19 \cdot 0 \\
4 \cdot 5-19 \cdot 5 \\
5 \cdot 6-24 \cdot 4 \\
6 \cdot 4-32 \cdot 8 \\
6 \cdot 8-44 \cdot 1\end{array}$} \\
\hline $\begin{array}{l}\text { Cord } \\
\text { Day } 2 \\
\text { Day } 3 \\
\text { Day } 4 \\
\text { Day } 5 \\
\text { Day } 6\end{array}$ & $\begin{array}{l}\because \\
\because \\
\because \\
\end{array}$ & $\begin{array}{l}. \\
\because \\
\because \\
\because \\
\therefore\end{array}$ & & & \\
\hline
\end{tabular}

TABLE II-Levels of Serum IgM in Control Infants and in Infants with Hepatosplenomegaly

\begin{tabular}{c|c|c}
\hline \multirow{2}{*}{ Range (mg/100 ml) } & \multicolumn{2}{|c}{ Number of Sera } \\
\cline { 2 - 3 } & Control Infants & $\begin{array}{c}\text { Infants with } \\
\text { Hepatosplenomegaly }\end{array}$ \\
\hline $0-<5$ & 0 & 1 \\
$5-<10$ & 81 & 30 \\
$10-<15$ & 45 & 31 \\
$15-<20$ & 11 & 6 \\
$20-<25$ & 4 & 15 \\
$25-<30$ & 0 & 4 \\
$30-<35$ & 0 & 0 \\
$45-<40$ & 0 & 2 \\
$70-<50$ & 0 & 1 \\
$>100$ & 0 & 30 \\
\hline Total & 141 & $29 *$ \\
No. with $20 \mathrm{mg} / 100 \mathrm{ml}$ & $4 *$ & $13.9 \dagger$ \\
\hline Geometric mean $(\mathrm{mg} / 100 \mathrm{ml})$ & $9 \cdot 6 \dagger$ & $3.3-58.3$ \\
\pm 2 S.D. (mg/100 ml) & $4.9-18.9$ & \\
\hline
\end{tabular}

*The difference is highly significant $(\mathrm{P}<0.001)$ by the $x^{2}$ test.

*The difference is highly significant $(\mathrm{P}<0.001)$ by the $x^{2}$ test.
tThe difference is highly significant $(\mathrm{P}<0.001)$ by the $t$ test.

of the control cord sera had levels of IgM less than $20 \mathrm{mg} / 100 \mathrm{ml}$. In the present study IgM levels of $20 \mathrm{mg} / 100 \mathrm{ml}$ or greater were therefore considered to be abnormally raised. In the control group 4 out of 141 (3\%) had raised IgM levels, whereas in the infants with hepatosplenomegaly 29 out of $97(30 \%)$ had raised IgM levels. The difference between the numbers with raised IgM levels in the two groups of infants is highly significant $(P<0.001)$ when analysed by the $\chi^{2}$ test. In the infants with hepatosplenomegaly the geometric mean level for IgM was $13.9 \mathrm{mg} / 100 \mathrm{ml}$ with \pm 2 S.D. of 3.3 to $58.3 \mathrm{mg} / 100 \mathrm{ml}$. When the $t$ test is applied the difference in the mean levels of the two groups of infants is found to be highly significant $(P<0.001)$.

A total of 138 cord sera from the control group of infants were examined for IgA levels. Only $49(35 \%)$ of them had detectable levels of $\mathrm{IgA}$, with the values ranging from 2.9 to $15.1 \mathrm{mg} /$ $100 \mathrm{ml}$ (Table III). The geometric mean IgA concentration in this group was $4.7 \mathrm{mg} / 100 \mathrm{ml}$ with \pm 2 S.D. of 2.0 to $7.4 \mathrm{mg} /$ $100 \mathrm{ml}$. The IgA concentrations found in the infants with hepatosplenomegaly were very similar to those of the control group. Of 93 infants with hepatosplenomegaly tested, 31 (33\%) showed detectable levels of IgA, ranging from 3.4 to $17.0 \mathrm{mg} /$ $100 \mathrm{ml}$. The geometric mean level was $5.0 \mathrm{mg} / 100 \mathrm{ml}$ with \pm 2 S.D. of 3.0 to $8.0 \mathrm{mg} / 100 \mathrm{ml}$.

\section{Discussion}

Many intrauterine infections may be inapparent at birth (Eichenwald, 1960; Miller et al., 1967; Alford, 1971). The measurement of IgM and IgA in newborn sera has been shown to be a useful screening procedure in the detection of such infections (Stiehm et al., 1966; Alford et al., 1967; Alford, 1971). In the IgM screening method $20 \mathrm{mg} / 100 \mathrm{ml}$ or greater in newborn sera has been considered abnormal by many investigators (Alford, 1971). This value for raised IgM was also used in the present study, since the upper limit of normal for cord IgM in our series was $18.9 \mathrm{mg} / 100 \mathrm{ml}$.

The association of raised IgM levels with hepatosplenomegaly in an appreciable proportion (30\%) of newborn infants with this abnormality is of interest. Intrauterine infections are a well-known cause of hepatosplenomegaly (Stern and Tucker, 1965; Overall and Glasgow, 1970) and the present finding seems to suggest such a relationship. However, hepatosplenomegaly in many infants was probably due to other causes, as shown by the failure to demonstrate raised IgM levels in most of these infants.

No difference was found in IgA concentrations in the two groups of newborn infants. In contrast to many reports (Alford, 1971 ), we found that a high proportion (35\%) of normal cord sera contained IgA with levels ranging from 2.9 to $15.1 \mathrm{mg} /$ $100 \mathrm{ml}$ and a mean level of $4.7 \mathrm{mg} / 100 \mathrm{ml}$. The mean IgA level in our series is somewhat higher than the level $(3.35 \mathrm{mg} / 100 \mathrm{ml})$ reported for newborns in Taiwan (Yang et al., 1970).

Further studies are in progress to identify the specific agents that caused the raised IgM levels in newborn infants with hepatosplenomegaly. Among the known pathogens that cause intrauterine infections are rubella virus, cytomegalovirus, herpes simplex virus, Treponema pallidum, and Toxoplasma gondii.

We thank Mr. Lim Ek Wang for his able technical help; Mr. C. Y. Tye, of the Department of Social Medicine and Public Health, for help with the statistical analyses; and the Medical Superintendent of Kandang Kerbau Hospital, Dr. S. B. Kwa, for permission to carry out this study.

\section{References}

Alford, C. A. (1971). Pediatric Clinics of North America, 18, 99. Alford, C. A., Schaefer, J., Blankenship, W. J., Straumfjord, J. V., and Cassady, G. (1967). New England Fournal of Medicine, 277, 437.

Eichenwald, H. A. (1960). In Proceedings of the International Conference on Pediatrics (Copenhagen, 1956), p. 41. Copenhagen, Munksgaard Pediatrics (Copenhagen, 1956), p. 41. Copenhagen,
McNicholl, B. (1957). Archives of Disease in Childhood, 32, 438 Mancini, G., Carbonara, A. O., and Heremans, J. F. (1965). Immunochemistry, 2, 235.

Miller, M. J., Seaman, E., and Remington, J. S. (1967). Fournal of Pediatrics,

70, 714. Overall, J. C., and Glasgow, L. A. (1970). Fournal of Pediatrics, 77, 315.

Stern, H., and Tucker, S. M. (1965). Lancet, 2, 1268.

Stiehm, E. R., Ammann, A. J., and Cherry, J. D. (1966). New England Fournal of Medicine, 275, 971 .

Yang, S. L., Kleinman, A. M., and Wei, P. Y. (1970). Southeast Asian fournal of Tropical Medicine and Public Health, 1, 401.

TABLB III-Levels of Serum IgA (mg/100 ml) in Control Infants and in Infants with Hepatosplenomegaly

\begin{tabular}{|c|c|c|c|c|c|c|}
\hline & & No. Tested & No. and $\%$ with IgA & Geometric Mean & \pm 2 S.D. & Range \\
\hline $\begin{array}{l}\text { Control infants } \\
\text { Infants with } \\
\text { hepatosplenomegaly }\end{array}$ & $\begin{array}{l}\cdots \\
\cdots\end{array}$ & $\begin{array}{r}138 \\
93\end{array}$ & $\begin{array}{l}49(35 \%) \\
31(33 \%)\end{array}$ & $\begin{array}{l}4 \cdot 7 \\
5 \cdot 0\end{array}$ & $\begin{array}{l}2 \cdot 0-7 \cdot 4 \\
3 \cdot 0-8 \cdot 0\end{array}$ & $\begin{array}{l}2 \cdot 9-15 \cdot 1 \\
3 \cdot 4-17 \cdot 0\end{array}$ \\
\hline
\end{tabular}

